\title{
Tendon-derived progenitor cells: In vitro characterization and clinical applications for tendon repair
}

\author{
Sushmitha S. Durgam and Matthew C. Stewart* \\ Department of Veterinary Clinical Medicine, College of Veterinary Medicine, University of Illinois, USA
}

\begin{abstract}
Tendinitis/tendinopathies are common performance-limiting injuries. The last decade has seen significant development in mesenchymal stem cell (MSC)based therapies in tendon repair. Using tendon-derived progenitor cells (TDPCs) for tendon healing is based on the rationale that stem cells from tendons are more phenotypically-committed or 'primed' for tenogenesis than cells from other tissues. This review article summarizes recent literature addressing the in vitro characteristics of TDPCs and evaluates their in vivo effects in experimental models of tendon repair. TDPCs share many of the common MSC properties; however express some lineage-specific characteristics that are heavily dependent on the extracellular matrix and tensile load stimulation. TDPCs are multipotent cells that undergo aberrant differentiation in an inflammatory milieu. In vivo experimental studies demonstrate that implanting TDPCs, alone or with biologic vehicles, improves the biomechanical and histological characteristics of repair tissue. However, TDPCs, like other MSCs used for in vivo tendon repair do not directly enhance the cellular pool within tendons. Recent evidence suggests that 'priming'TDPCs for tenogenesis during in vitro culture and administering these cells along with acellular matrix may augment the efficacy of TDPC-based therapies. Further research focusing on delineating the phenotype of TDPCs, and establishing optimal cell delivery strategies that influence healthy tendon repair are warranted to optimize TDPC-based treatment of tendon pathology.
\end{abstract}

\section{Introduction}

Tendon injuries range from acute tendon rupture to chronic tendinopathy, and are among the most common orthopedic problems. Achilles tendon injuries account for up to $50 \%$ of all sports-related injuries [1,2], while rotator cuff degenerative tendinopathy is a common cause of shoulder pain/disability [3]. Flexor tendon injuries are linked to several occupations in people [4] and in sport/performance horses [5]. Further, long-term disability is a frequent consequence, due to prolonged healing time and high rate of recurrence following the initial injury [6,7]. Consequently, the financial impact of tendon injuries is considerable.

Tendons are highly specialized connective tissues that transmit tensile forces between muscles and bones. Tendons are relatively hypocellular and hypovascular tissues, with little or no intrinsic regenerative capacity. Current therapies involve conservative management and/or surgical debridement and repair, depending on the location and severity of the pathology $[8,9]$. Irrespective of the approach used, the resultant repair tissue is biomechanically inferior to healthy tendon and re-injury is common despite prolonged rehabilitation. Consequently, cell-based approaches to tendon healing have been widely investigated in experimental models of tendinitis with the goal of improving the quality of repair tissue. Mesenchymal stem cells (MSCs) derived from different sources have been evaluated in both in vitro and in vivo models of tendon repair and the outcomes have been recently reviewed [10-15]. This review will specifically focus on tendon-derived stem/progenitor cells, their in vitro and in vivo characteristics, and their efficacy in improving tendon healing in experimental models. Several different terms have been used in the literature to describe the stem/progenitor cell populations within tendons. In this review, the term "tendon-derived progenitor cells" (TDPCs) is used to refer to these cells.

\section{Tendon structure and function}

Tendons are dense collagenous tissues that connect muscles to bones and are composed of a hierarchical arrangement of predominantly collagenous subunits (Figure 1). Morphologically, tendons contain a variable number of fascicles, which are comprised of multiple collagen fiber bundles. The fiber bundles contain many collagen fibrils [16,17]. These collagen units are oriented in the direction of the predominant tensile load. Tendon fascicles are bound together by a loose areolar connective tissue, the endotenon, which becomes confluent with the outer epitenon. The epitenon is surrounded by the peritenon; a fine connective tissue sheath which functions as an elastic sheath to permit free movement of the tendon against the surrounding structures. The collagen molecules are stabilized by intermolecular chemical crosslinks resulting in high tensile strength [18].

Histologically, tendons have a highly organized and anisotropic structure (Figure 2). Collagen fibers are aligned along the longitudinal axis in each fascicle. Tenocytes are located both within and between the fascicles, arranged in rows along the direction of the collagen fibers [19]. A characteristic crimp pattern of collagen fibers is a typical ultrastructural feature of tendons (Figure 3A). The crimps function as a buffer to provide immediate longitudinal elongation in response to physiological tensile loads [17].

Tendons can be classified as positional or energy-storing tendons.

Correspondence to: Matthew C Stewart, 1008 W. Hazelwood Drive, Urbana, IL61802, USA, Tel: 217-265-5206, Fax: 217-244-1475, E-mail: matt1@illinois.edu

Key words: tendon-derived progenitor cells (TDPCs), tendon-derived stem cells, tendinitis, tendinopathy, cell-based therapies

Received: April 01, 2016; Accepted: May 13, 2016; Published: May 16, 2016 


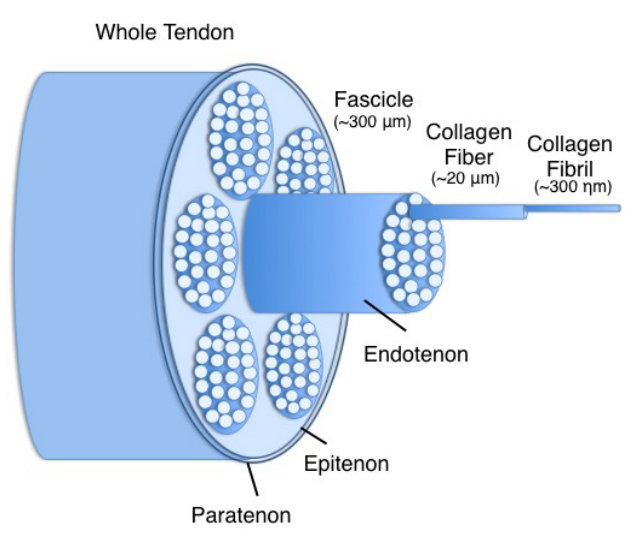

Figure 1. Schematic representation of hierarchical structure in tendons.

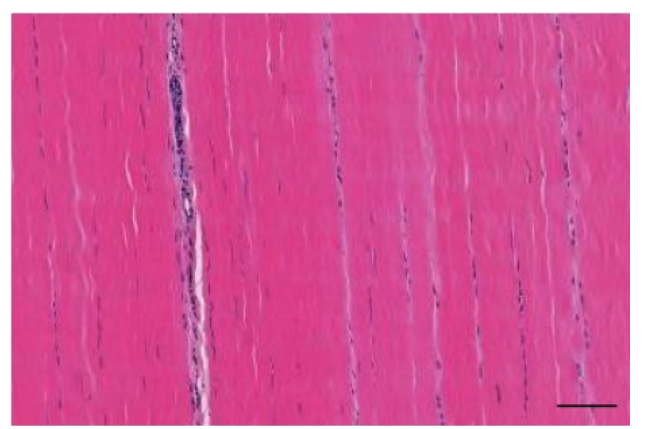

Figure 2. Hematoxilin and eosin stained, bright-field microscopy image of a longitudinal section of normal equine tendon. Scale bar $=100$ microns.

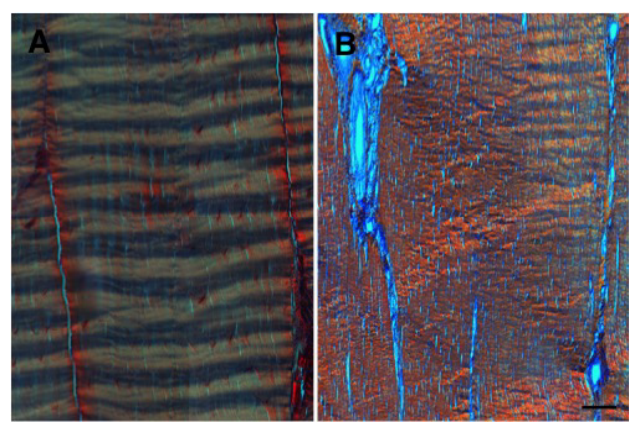

Figure 3. Picro-Sirius Red stained, polarized light microscopy image of a longitudinal section of (A) normal and (B) chronically injured (16-weeks post collagenase-injection) equine superficial digital flexor tendon. Scale $b a r=100$ microns.

All tendons transmit forces from muscle to bone; however, energystoring tendons have the additional function of extension and recoil to increase the efficiency of locomotion [19]. Tendons respond to tensile loads at multiple structural levels [20,21]. Crimp elongation provides a relatively modest (approximately $3 \%$ ) strain response to load. Elastic 'sliding' between adjacent fibers, fibrils and fascicles, rather, than direct 'unit' extension, provides the majority of tensile strain. In addition, recent evidence suggests the presence of helical substructures within the tendon fascicles, which provides a mechanism for efficient extension under load and recoil when unloaded [22]. Therefore, the collective mechanical properties of both the interfascicular and intrafascicular matrices are responsible for the functional capacity of tendons.

\section{Endogenous tendon healing}

Healing tendons undergo the traditional phases of an initial inflammatory response, a proliferative phase and a remodeling phase
[5]. The reactive inflammatory phase lasts for about a week, in the absence of ongoing injury, and is characterized by a marked increase in cross-sectional area at and around the site of injury, consequent to local hemorrhage and edematous swelling. This is followed by inflammatory cell infiltration, primarily neutrophils and macrophages. The proliferative phase overlaps with the latter half of the inflammatory phase and peaks in about 2-3 weeks. Neovascularization, local synthesis of chemokines, trophic factors and proliferation of fibroblasts are dominant features of this phase. These processes culminate in tenocyte proliferation and collagen synthesis leading to formation of immature fibrovascular tissue. The remodeling phase is characterized by formation of fibrous tissue. During this stage, the healing tissue undergoes changes in size and shape. This phase is divided into consolidation and maturation processes [23]. The repair tissue transitions from predominantly cellular to fibrous in nature, as new matrix is synthesized at the injury site. However, increased vascularity, neuronal infiltration and cellularity persist for up to 3 months postinjury $[6,24,25]$ and the collagen architecture remains disorganized for several months (Figure 3B). This results in reduced extensibility and elasticity of the repair tissue and predisposes the site to re-injury.

\section{Tendon-derived progenitor cells}

The focus on TDPCs for tendon regeneration is based on the rationale that cells derived from the target tissue (in this case, tendon) will be phenotypically and biosynthetically more capable of stimulating functional repair than MSCs derived from other tissue sources. The existence of MSCs in tendon tissue was first reported in 2003 [26]. Tendon-derived cell lines expressing tendon phenotype-related genes such as scleraxis, cartilage oligomeric matrix protein (COMP), and type I collagen (in addition to osteopontin and Runx2), were developed from transgenic mice. Bi et al. (2007) identified and characterized a unique cell population, termed tendon stem/progenitor cells, from mouse and human tendon samples [27]. These cells demonstrated universal stem cell characteristics of clonogenicity, multipotency and selfrenewal capacity. This study also showed that the bioactivity of TDPCs, like other MSCs, is heavily dependent on their local environment/ matrix interactions ('niche'). Comprehensively characterizing stem/ progenitor cells in tendons and their role in tendon responses to injury is paramount for developing effective regenerative therapies.

\section{In vitro characteristics of TDPCs}

TDPC isolation: TDPCs have been isolated from fetal [28] and adult human, murine [27], rat [29], lapine [30] and equine [31,32] tendons. TDPCs are typically isolated via collagenase type I digestion followed by low-density plating. Most studies have used an initial seeding density of $5 \times 10^{2} \mathrm{cells} / \mathrm{cm}^{2}$, however the optimal seeding density for TDPC isolation has not been established. Cell surface epitope-based selection $\left(\mathrm{CD} 0^{+}, \mathrm{CD}^{2} 3^{+}, \mathrm{CD} 105^{+}\right.$and $\left.\mathrm{CD} 45^{-}\right)$for TDPC isolation from tendon digests has also been attempted. However, this technique does not separate tenocytes and fibroblasts from TDPCs, as markers specific for tenogenic lineage are lacking $[33,34]$. Other techniques of TDPC isolation include cell migration from tendon explants [27], differential adhesion of isolated cells [32,35], colony isolation [30] and selective substrate adhesion to fibronectin [31]. No clear benefits of the latter techniques over standard low-density plating have yet been identified. Currently, enrichment of TDPCs relies on multiple passage subculture, to enrich for rapidly and persistently proliferative stem cells from initial heterologous tendon digest populations [36].

Donor age may influence the number, proliferative and multi- 
lineage capacities of TDPCs. The total number of TDPCs in aged rats decreased by $70 \%$ compared to young rats [37]. In human isolates, proliferation and clonogenicity of TDPCs from aged tendons was decreased although their multi-lineage potential was retained [38]. Age did not affect in vitro characteristics in equine TDPCs [31], suggesting that species-specific differences in age-dependent in vitro characteristics of TDPCs exist.

TDPCs have been isolated from rat and murine Achilles and patellar tendons, lapine Achilles tendon, human patellar, Achilles, rotator cuff and biceps tendons, and equine extensor and flexor tendons. Clear differences in the characteristics of TDPCs isolated from different tendons have not been demonstrated, but the number and biosynthetic activity of TDPCs are increased in response to physiologic loading and exercise, [39], and the stem/progenitor cell populations derived from the peritenon and tendon proper are distinct [40-42]. Tendon proper-derived TDPCs were more permissive for in vitro tenogenic differentiation than peritenon-derived progenitor cells. Further investigation into this aspect of TDPC biology is warranted, since these sub-populations may have distinct functions and efficacies in intrinsic and extrinsic tendon healing.

In vitro expansion and proliferation: Using TDPCs to treat tendon injuries is dependent on efficiently expanding these cells to clinically relevant numbers while maintaining their 'stemness' and therapeutic value during multiple passages. TDPCs, like other MSCs, proliferate more rapidly than terminally differentiated tenocytes during in vitro expansion [30]. Culturing human TDPCs in reduced oxygen conditions increases proliferation [43-45], metabolic rates and biosynthetic activities [40] but in one of these studies [43], 2\% oxygen levels reduced their multi-lineage potency. Similarly, equine TDPCs isolated via low-density plating and cultured under hypoxic conditions had higher proliferation rates than TDPCs cultured in normoxic conditions [31]. The effect of passage on the in vitro characteristics of TDPCs has received little attention, and the existing data is not consistent. Zhang et al. (2010) reported that the proliferation of porcine TDPCs decreased as the passage number increased [44]. In contrast, Tan et al. (2012) found that the proliferation rate and colony-forming ability of rat TDPCs increased with subsequent passages [46]. More research will be necessary to clarify this issue and determine speciesspecific consequences of multiple passages on subsequent activities.

Immunophenotypic profile: TDPCs share common stem cell markers identified in MSCs from other tissue sources. Specific markers that distinguish TDPCs from terminally differentiated tenocytes are poorly defined. TDPCs express CD44, CD90, CD146, CD73, Sca-1, Stro-1, nucleostemin, Oct-4, SSEA-4 and are negative for CD31, CD34, CD45, CD144, CD106 [27-31,40,44]. These markers cannot distinguish TDPCs from other MSCs and some these MSC markers are, in fact, fibroblast markers (CD44 and CD90). On the other hand, certain markers that distinguish TDPCs from bone marrow MSCs have been identified. Murine and human TDPCs lacked CD18 expression, which is expressed by bone marrow MSCs [27]. CD106 is expressed by human and rat TDPCs but is absent in bone marrow MSCs. Phenotypic markers expressed in TDPCs isolated from different species are summarized in Table 1.

The specific source of TDPCs may also affect their immunophenotype. Approximately $90 \%$ of TDPCs from tendon proper expressed Sca- 1 whereas only $70 \%$ of peritenon-derived TDPCs expressed this marker [41]. As expected, TDPCs isolated from peritenon had higher expression of CD133 (a pericyte marker) than TDPCs from tendon proper. A similar study found that TDPCs from peritenon were $\mathrm{CD} 146^{+}$, CD34; TDPCs from interstitial tissue were CD146, $\mathrm{CD}_{34}^{+}$; and TDPCs from tendon proper were CD146, CD34. All three populations were $\mathrm{CD} 44^{+}, \mathrm{CD} 31^{-}$and $\mathrm{CD}^{-} 5^{-}$[40]. These findings must be interpreted with caution as these results were largely derived from rat patellar tendon-derived TDPCs and the study sample sizes were low. Further research addressing the regional immunophenotypic characteristics of TDPCs is required to understand the link between immunophenotype and clinical efficacy.

Due to a relatively small proportion of progenitor cells in tendon, most studies analyze the immunophenotype of TDPCs after a short period of sub-culture. The immunophenotype of TDPCs, as with other MSCs, changes during in vitro passaging. One study reported the Expression of CD146, CD73 and CD90 in freshly isolated rat patellar TDPCs is lost after in vitro culture [46,47]. Kowalski et al. (2015) reported that although in vitro passaging altered the expression of CD34 and CD44 in the three sub-populations of TDPCs, their overall pattern of expression was unchanged [40]. These findings suggest that any protocol for TDPC selection based on immunophenotype will need to accommodate the alterations that occur with in vitro culture.

\section{Multipotency of tendon-derived progenitor cells}

In vitro differentiation: TDPCs, like other MSCs, are able to

Table 1. Summary of in vivo TDPC-based tendon repair models.

\begin{tabular}{|c|c|c|c|c|c|c|c|}
\hline Tendon & Species & Model & Source of TDPCs & $\begin{array}{l}\text { In vitro Culture } \\
\text { And Expansion }\end{array}$ & Vehicle Used & $\begin{array}{l}\text { Duration of } \\
\text { The Study }\end{array}$ & Reference \\
\hline Patellar & Rat & Patellar tendon window defect & Rat patellar tendon-derived & Low density plating & Fibrin glue & 4 weeks & [104] \\
\hline Patellar & Rat & Patellar tendon window defect & Rat patellar tendon-derived & Low density plating & Fibrin glue & 16 weeks & [98] \\
\hline Patellar & Rat & Patellar tendon window defect & Rat patellar tendon-derived & $\begin{array}{l}\text { Low density plating }+ \\
\text { CTGF }(25 \mathrm{ng} / \mathrm{mL}) \text { and Ascorbate }(25 \mathrm{uM})\end{array}$ & $\begin{array}{l}\text { Scaffold-free cell } \\
\text { construct }\end{array}$ & 8 weeks & {$[112]$} \\
\hline Patellar & Rat & Patellar tendon window defect & Rat patellar tendon-derived & $\begin{array}{l}\text { Low density plating }+/ \text { - } \\
\text { CTGF }(25 \mathrm{ng} / \mathrm{mL}) \text { and Ascorbate }(25 \mathrm{uM})\end{array}$ & Fibrin glue & 16 weeks & [113] \\
\hline Patellar & Rat & Patellar tendon window defect & Rat patellar tendon-derived & $\begin{array}{l}\text { Low density plating and lentiviral-induced Scleraxis } \\
\text { overexpression }\end{array}$ & Fibrin glue & 8 weeks & [119] \\
\hline Patellar & Rat & Patellar tendon window defect & $\begin{array}{l}\text { Rat and Human patellar-tendon } \\
\text { derived }\end{array}$ & $\begin{array}{l}\text { Low density plating } \\
+ \text { in-vitro culture with decellularized tendon matrix }\end{array}$ & Tendon Matrix gel & 8 weeks & {$[99]$} \\
\hline Patellar & Rat & Patellar tendon window defect & $\begin{array}{l}\text { Rat and Human patellar-tendon } \\
\text { derived }\end{array}$ & $\begin{array}{l}\text { Low density plating } \\
+ \text { in-vitro culture with dermal fibroblast matrix }\end{array}$ & $\begin{array}{l}\text { Dermal fibroblast } \\
\text { matrix }\end{array}$ & 8 weeks & {$[120]$} \\
\hline Achilles & Rat & Achilles transection & Rat Achilles-derived & Low density plating & Collagen sponge & 2 weeks & [116] \\
\hline Achilles & Rat & Collagenase & $\begin{array}{l}\text { Rat Achilles- } \\
\text { derived }\end{array}$ & $\begin{array}{l}\text { Low density plating }+ \\
10 \% \text { PRP releasate to P2 TDPCs for } 3 \text { days }\end{array}$ & PRP & 8 weeks & {$[117]$} \\
\hline $\begin{array}{l}\text { Superficial } \\
\text { digital flexor }\end{array}$ & Horse & Collagenase & $\begin{array}{l}\text { Lateral digital extensor tendon- } \\
\text { derived }\end{array}$ & Differential adhesion selection & Saline & 12 weeks & {$[105]$} \\
\hline
\end{tabular}


differentiate into adipogenic, osteogenic and chondrogenic lineages when exposed to appropriate stimuli (Figure 4). Allowing for interspecies variability, the reported in vitro tri-lineage differentiation potential of TDPCs isolated from healthy tendons has been inconsistent across studies. Earlier seminal studies characterizing TDPCs reported equivalent differentiation along adipogenic, osteogenic and chondrogenic pathways $[26,27,48]$. In contrast, more recent studies have reported restricted adipogenic capacity of TDPCs isolated from normal tendons [31,49]. In vitro culture conditions can also affect the differentiation potential of TDPCs. Hypoxia during in vitro culture enhanced the differentiation capacity of human TDPCs [45] although equine TDPCs were unaffected by hypoxia [31]. Further, in vitro passage decreased the adipogenic and chondrogenic differentiation of TDPCs while their osteogenic capacity was increased [50].

The comparative differentiation potentials of TDPCs and bone marrow MSCs have also been investigated. de Mos et al. (2007 and Randelli et al. (2013) demonstrated that the tri-lineage potential of TDPCs and bone marrow MSCs were similar [33,48], whereas Tan et al. (2012) showed that TDPCs had a higher adipogenic, osteogenic and chondrogenic potential than bone marrow MSCs [50]. TDPCs have higher BMP receptor expression and are more responsive to BMP-2induced osteogenic differentiation than bone marrow MSCs [36].

Data on the influence of donor age on TDPC multipotency is not consistent. TDPCs isolated from aged rat tendon underwent adipogenesis more readily and expressed higher levels of adipogenic markers (PPAR $\gamma$, leptin) than their younger counterparts, whereas the osteogenic and chondrogenic capacity of TDPCs was unchanged [37]. However, more recent study that compared activities of human hamstring and Achilles tendon-derived TDPCs did not identify an effect of donor age on tri-lineage differentiation characteristics of TDPCs $[38,51]$. It is likely that species- and donor site-specific differences in the respective TDPC populations contributed to the disparities in outcome. Regardless, the influence of age on TDPC activity requires further investigation, given that degenerative tendinopathy is more prevalent in older individuals.

The in vitro differentiation potential of TDPCs isolated from healthy tendon tissue and pathological tissue are markedly different. TDPCs isolated from injured tendon had a higher in vitro chondrogenic potential than TDPCs from normal tendon [52]. These cells were implicated in chondro-degeneration noted during tendon healing and were characterized as $\mathrm{CD} 105$ cells. A follow-up study by the same group demonstrated that in vitro culture of TDPCs isolated from injured tendon treated with IL-1b decreased their trilineage differentiation potential. Further research on this aspect of TDPC pathobiology is required to determine whether cells isolated from pathological tissue during reparative surgeries can be used for consequent cell-based therapies [53]. Further, given the detrimental effects of inflammatory cytokines on TDPC activities, it will be critical to define the optimal

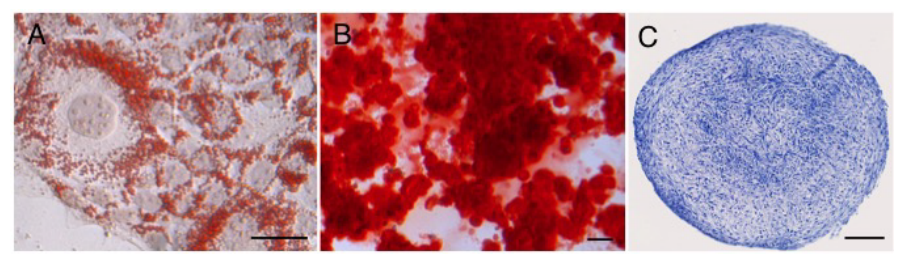

Figure 4. Trilineage differentiation of equine TDPCs. (A) Oil-Red-O staining of TDPCs after 14 days in adipogenic medium. (B) Alizarin Red staining of TDPCs after 14 days in osteogenic medium. (C) Toluidine blue-stained TDPC pellet at day 20 in chondrogenic medium. In all panels, bar $=100$ microns. time (following injury) for cell delivery to avoid aberrant responses of stem cells implanted in an active inflammatory milieu.

Aberrant TDPC differentiation in tendinopathy: Fatty degeneration, chondrogenic dysplasia and ectopic calcification within the repair tissue of chronically injured tendons are well-documented [54-63]. Ectopic chondro-ossification in the mid-substance of Achilles and patellar tendons occurred as a consequence of endochondral ossification $[63,64]$, reflecting a major phenotypic shift within the tendon cell population. The underlying pathogenesis for these metaplastic changes in chronic tendonopathy is poorly understood. Abnormal matrix deposition likely occurs from extrinsic cells that migrate to the site of injury [65] or from native tenocytes and/or TDPCs that undergo trans-differentiation to non-tenogenic phenotypes.

Experimental evidence indicates that alterations in matrix components within tendon repair tissue can profoundly impact the phenotype of TDPCs. TDPCs isolated from the biglycan-fibromodulin double knockout mice had increased collagen type II and aggrecan expression compared to wild-type TDPCs [27]. In vivo, TDPCs isolated from these mice formed bone in addition to tendon-like tissue, while the wild type TDPCs formed tendon-like tissue only. Asai et al. (2014) showed that TDPCs in injured tendons trans-differentiate into chondrogenic cells and induce chondro-degenerative lesions [52]. The molecular pathogenesis of aberrant TDPC differentiation in tendinopathy has not yet been fully elucidated, but several recent studies have implicated inflammatory cytokines, TGF- $\beta /$ BMP signaling, extracellular matrix changes and altered biomechanical stimuli in these phenotypic shifts.

Inflammatory cytokines and biological factors: The proinflammatory cytokines IL- $1 \beta$, IL- 6 and TNF $\alpha$ are up-regulated in both acute and chronic strain type injuries [66-68], inducing expression of inflammatory mediators Cox-2, PgE2, and collagenases MMP-1 and -13. All these factors are known to be involved in tendon matrix degradation [69]. TDPCs isolated from injured tendon and cultured in the presence of IL-1 $\beta$ irreversibly lose their tenogenic identity and increase their chondrogenic and osteogenic capacities [53].

TGF $\beta$ signaling is critical to fibrosis and scar formation in connective tissues and has also been implicated in pathogenesis of tendon injury $[57,70,71]$. TGF $\beta$ signaling activity, from TGF $\beta-1$ in particular, is increased in injured tendon, particularly in regions of chondrogenic metaplasia and heterotopic ossification $[63,64]$. Excessive TGF $\beta$ signaling also stimulates pro-inflammatory effects and tenocyte apoptosis [70]. TGF $\beta$ alters the metabolic activities of tenocytes during healing, increasing collagen secretion and consequent scar tissue formation, providing a therapeutic rationale for TGF $\beta$ signaling blockade. In support of this concept, attenuation of TGF $\beta$ signaling by targeting TGF $\beta-1$, CTGF and Smad 3 with anti-sense oligonucleotides reduced scarring and adhesion formation in a murine flexor tendon repair model [72]. Further, the chondro-degenerative lesions induced by injured TDPCs in healing tendons are dependent on TGF $\beta$ signaling [52].

Chondro-osteogenic BMPs, such as BMP-2, BMP-4, BMP-6 and BMP-7, promote cartilage, bone and bone-tendon junction repair [7377]. Several lines of evidence implicate dysregulation of BMP activity in tendinopathy as a cause of ectopic calcification. Ectopic overexpression of BMPs is observed in naturally occurring calcifying tendinopathy and experimental models of tendinitis [78,79], and intra-tendinous administration of rhBMP-2 results in ectopic calcification [80]. Murine TDPCs exposed to BMP-2 during in vitro culture prior to subcutaneous 
implantation into immuno-compromised mice generated enthesis-like elements comprised of both tendon-like and osseous tissues [27].

Altered tendon matrix composition: Disorganized collagen matrix, increased non-collagenous ground substance and an increased number and rounded morphology of the tenocytes are hallmarks of injured tendon $[81,82]$. During the healing process of experimental and naturally occurring tendinitis, the levels of large proteoglycans and sulfated glycosaminoglycans (characteristic of cartilage matrix) increase within tendon matrix [62,83-85]. These changes reduce the elasticity and tensile strength of the repair tissue. Proteoglycans such as biglycan, decorin, fibromodulin and lumican, although constituting a very small portion of tendon ECM, are active participants in collagen fibrillogenesis [86-89] and can also bind and sequester growth factors such as TGF $\beta$ and IGF-I [52,70,90-92] to modulate TDPC activities.

Altered tendon biomechanics: TDPCs, like terminally differentiated tenocytes, are sensitive to repetitive tensile loading in vitro $[30,93]$. Short-term treadmill exercise increased the yield of TDPCs from murine Achilles and patellar tendons. Further, the TDPCs isolated from exercised mice had higher biosynthetic activities than control mice. In vitro exposure to $4 \%$ tensile strain promoted tenogenic differentiation, whereas $8 \%$ tensile strain induced osteogenic differentiation [30]. TDPCs exposed to in vitro mechanical loading increased BMP-2 expression and had a higher osteogenic potential compared to unloaded TDPCs [93]. A recent study demonstrated that applying in vitro biaxial mechanical stress induces the expression of the proteoglycans, fibromodulin, lumican and versican in TDPCs [94]. These findings provide a mechanistic explanation for ectopic calcification that occurs as a result of mechanical overloading. The combination of excessive loading, BMP up-regulation and alterations in non-collagenous protein expression could generate conditions favoring TDPC chondro-osteogenesis, at the expense of tenogenic differentiation.

\section{Applications of tendon-derived progenitor cells in ten- don regeneration}

Stem cell implantation has improved tendon healing in most studies [reviewed in 10,11,14,15]. Accepting the experimental benefits of stem cell-based therapies, several factors must be considered while choosing a particular cell type to treat tendon injuries. The tissue source must be easily accessible with acceptable donor site morbidity. The requirements for vitro manipulation (expansion and phenotypic modulation) should be minimized, to mitigate the risks of contamination and 'chain of custody' lapses. Finally, the phenotypic and reparative activities of the therapeutic cell type should closely match the target tissue. In this respect, tenogenically-committed stem/progenitor cells derived from tendons seem more appropriate for tendon regeneration than MSCs obtained from other tissue sources.

\section{In vitro evidence supporting TDPCs for tendon regeneration}

Several recent studies have evaluated the tenogenic potential of TDPCs under in vitro conditions. Acellular tendon has been used in tissue-engineering studies as a scaffold in cell-based approaches for flexor tendon injuries in murine models $[95,96]$. Decellularization of tendons was carried out by freeze-thaw cycles followed by trypsin digestion. Co-culturing TDPCs with acellular tendon matrix in vitro significantly increased their tenogenic marker expression and subsequent tenogenic differentiation. This acellular tendon-matrix model has been used by our group for comparative analyses of equine TDPCs and bone marrow for tendon healing $[97,98]$. TDPCs were more viable and showed superior integration into acellular tendon matrices than bone marrow MSCs (Figure 5). In addition, TDPCs had significantly higher collagen and proteoglycan synthesis levels than bone marrow MSCs. A follow-up study showed that supplementing FGF-2 during monolayer expansion of TDPCs potentiated the biosynthetic activities of TDPCs compared to bone marrow MSCs during in vitro culture with pulverized acellular tendon matrix [35]. Human fetal TDPCs cultured in aligned nanofibrous scaffold supported tenogenesis and suppressed osteogenic differentiation [28]. Collectively, these results indicate that TDPCs respond to tendon matrix components by adopting a biosynthetically active tenogenic phenotype, supporting the strategy of implanting these cells into healing tendon lesions.

\section{In vivo evidence supporting TDPCs for tendon regeneration}

The benefits of cell-based treatments for experimental tendon defects were first reported in 2002. Autologous tenocyte constructs were used to bridge partial flexor tendon defects in adult chickens [99]. Fourteen weeks following implantation of tenocytes, the histologic structure and biomechanical properties of the tenocyte-treated tendons were significantly improved compared to the untreated controls. Since the discovery and characterization of TDPCs, several studies have evaluated the reparative activity of TDPCs in in vivo models of tendon injury. These studies are summarized in Table 1.

Ni et al. (2012) were the first to investigate the in vivo healing characteristics of TDPCs in a rat patellar tendon window defect model [100]. GFP-labeled TDPCs in a fibrin glue matrix were injected into the defect. TDPC numbers at the site of injection decreased over time and were completely absent by four weeks after implantation. TDPC implantation improved the histologic, biomechanical and ultrasonographic characteristics of patellar tendon healing. No ectopic bone formation was detected at 4 and 16 weeks post-injury, which were the end-points of this two-part study. A subsequent study by the same group evaluated the effect of rat patellar tendon-derived TDPCs transduced with scleraxis (SCX) in the same model [101]. The

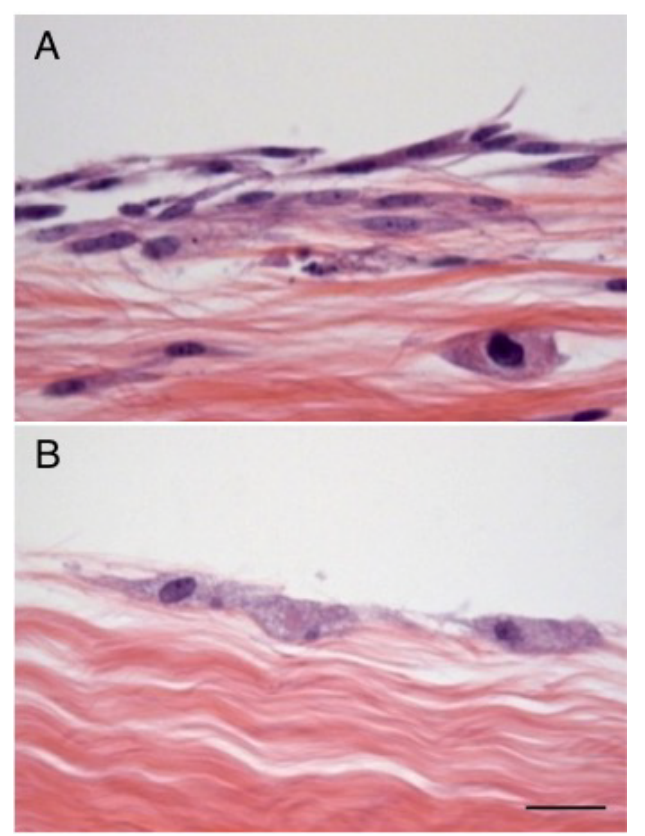

Figure 5. (A) TDPCs and (B) bone marrow MSCs seeded on acellular tendon matrices demonstrate differential colonization of tendon explants and some penetration by TDPCs into the underlying matrix. Scale bar $=100$ microns. 
histological and biomechanical characteristics of TDPC-Scx treated tendons were significantly better than tendons treated with TDPCs transduced with empty viral vector, suggesting that genetically priming TDPCs for tenogenic differentiation is clinically beneficial, although an alternative to viral delivery will likely need to be developed prior to approval for clinical applications.

A recent study by our group evaluated the effect of autologous TDPCs in a collagenase-induced equine flexor tendinitis model [102]. The TDPCs were implanted four weeks after tendinitis induction, and improved the biomechanical and histological characteristics of the tendons, 12 weeks following administration. The biochemical and transcriptional outcomes were not significantly influenced by TDPC injection. Similar to the findings of Ni et al. (2012) [100], TDPCs were not detected at the injection sites beyond 4 weeks after treatment. Significant improvements in collagen micro-architecture have also been reported in this equine model, following bone marrow MSC [103], adipose-derived MSC [104] and fetal-derived embryonic stem cell [105] administration. The biomechanical consequences of these other progenitor types have yet to be determined and the relative merits of these stem cell populations for tendon repair have yet to be defined in direct comparative studies.

Accepting the multipotency of TDPCs, priming TDPCs for tenogenic differentiation during in vitro culture and expansion has been investigated to avoid abnormal matrix deposition within the healing tissue [106]. Connective tissue growth factor (CTGF) is highly expressed during early stages of tendon repair [107]. In addition, CTGF stimulates tenogenic differentiation of TDPCs in vitro, when supplemented with ascorbic acid [108]. Rat patellar tendon-derived TDPCs were cultured with CTGF and ascorbic acid for two weeks to produce a thin cellular sheet, before being transplanted into patellar tendon window defects [109]. The biomechanical and histologic characteristics of the TDPC-treated tendons at 2,4 , and 8 weeks were improved compared to un-treated controls. A recent follow-up study by the same group included an additional experimental group in which untreated TDPCs in a fibrin glue matrix (i.e., cultured without CTGF and ascorbic acid) were implanted into the patellar tendon window defect [110]. The biomechanical, histological and ultrasonographic characteristics of tendons defects treated with TDPCs that were exposed to CTGF and ascorbic acid were significantly better than defects treated with control TDPCs, suggesting that pre-implantation 'priming' of TDPCs will be clinically beneficial.

Autologous products like platelet-rich plasma (PRP) can also be administered with TDPCs to enhance tendon repair. Intralesional PRP administration alone has improved the overall healing characteristics of repair tissue in experimental models of tendinitis [111,112]. In vitro, platelet-rich clot releasate stimulates tenogenic differentiation of TDPCs while inhibiting osteogenic differentiation [113]. TDPCs and PRP synergize to stimulate collagen gene expression of healing rat Achilles tendons [114]. In a follow up study by the same group, passage 2 TDPCs were cultured with platelet-rich clot releasate for 3 days prior to in vivo administration [115]. TDPCs supplemented with PRP prior to intralesional administration significantly improved the overall healing characteristics of the Achilles tendon compared to control TDPCs. These findings support the hypothesis that PRP likely augments the local trophic factor synthesis and cytokine modulatory effects of TDPCs and improves reparative effects, while also acting as a bio-compatible delivery vehicle.

\section{TDPCs in tissue engineering}

TDPC activities are heavily influenced by extracellular matrix. Given that there is gross disruption of tendon matrix in acute injuries and major changes in extracellular matrix composition in chronic tendinopathy, incorporating TDPCs in an appropriate 'teno-inductive' scaffold may improve tissue repair, in comparison to direct injections of TDPCs. Biological scaffolds seeded with differentiated tenocytes and bone marrow MSCs have improved repair of tendon defects in several in vivo models [reviewed in 13]. Similar approaches using TDPCs have been evaluated in a few studies.

Zhang et al. (2009) prepared decellularized matrix by pulverizing and nuclease-digesting tendon. This matrix promoted proliferation and tenogenic differentiation of human and rat patellar tendon-derived TDPCs in vitro [95]. Subsequently, TDPCs cultured with decellularized tendon, or TDPCs alone were implanted subcutaneously, along the dorsal midline, and into patellar tendon window defects of nude mice. Interestingly, TDPCs cultured with tendon matrix synthesized neotendon tissue whereas naïve TDPCs did not form recognizably tendonlike tissue at either site. A decellularized matrix prepared from dermal fibroblasts was used to support rat and human patellar tendon-derived TDPCs for one week prior to in vivo implantation in a similar in vivo model [116]. Co-culturing TDPCs with dermal fibroblast-derived matrix promoted tenogenic differentiation in vitro and neo-tendon formation in vivo, whereas these effects were not seen with control TDPCs. Given that matrices from both tendinous and non-tendinous sources support proliferation and tenogenic differentiation of TDPCs, an appropriate bio-matrix could optimize the therapeutic value of these cells after in vivo delivery, although implantation of semi-solid cell-matrix composites is clearly more invasive and complicated than percutaneous injection.

\section{Future directions and conclusions}

Understanding the basics of TDPC biology is critical for their successful application in tendon repair/regeneration. To date, markers specific to TDPCs and tenocytes in general are poorly defined, and a reliable in vitro tenogenic differentiation assay is still lacking, although research efforts in this area are ongoing. TDPCs are heterogeneous cells and therefore developing a single marker that can definitively identify TDPCs is likely not feasible. Studies focusing on identifying a panel of co-expressed markers to define TDPCs are more realistic. Selfevidently, determining whether any given immunophenotypic tendonderived sub-population holds any therapeutic advantage will also need to be addressed in rigorous in vivo models.

TDPCs and their fate in tendon tissue can vary considerably on the physiological or pathological status of the tissue. As our current understanding of the mechanisms controlling tendon pathology and repair are limited, identifying the cellular phenotype(s), and delineating the biological and molecular processes influencing healthy tendon repair will be critical. Fetal tendon defects heal via an authentic regenerative process, unlike adult tendons [117]. Elucidating the reparative mechanism of fetal healing may provide insights to enable the recapitulation of regeneration in adult tendons. As detailed above, this will likely involve modulating TGF $\beta$ signaling in the healing tendon.

Tendon healing in experimental models has been substantially improved with cell-based and other biologic approaches, although these therapies do not completely restore the tissue microarchitecture. With the data from recent cell-tracking studies, it is well established 
that exogenous stem cells are cleared from the injection site within a few weeks and do not directly contribute to the pool of tenocytes and/or progenitor cell participating in tendon repair/regeneration $[32,118,119]$. Future studies focusing on cytokines and/or trophic factors secreted by TDPCs that mediate their therapeutic effects could simplify therapy considerably. Optimizing stem cell delivery by combining cells with teno-inductive scaffolds may retain cells at the implantation site for longer periods of time, with correspondingly longer therapeutic actions.

Restoring the biomechanical function of repair tissue should be the ultimate goal of any regenerative therapy for treating tendon injuries. Tendons respond to tensile loads via elongation and sliding between each element of the hierarchical structure. As the gross and microscopic structure of tendons is disrupted in tendon injury, the ideal regenerative therapy must restore the hierarchical structure of tendons and the sliding mechanisms of the tendon components, in addition to improving collagen alignment to regain full biomechanical function. Currently, collagen fiber pattern along the long axis of the tendon is the major outcome parameter used to assess tissue morphology but this does not address restoration of tertiary structure. Developing non-invasive and histological techniques that comprehensively assess tendon histology at multiple levels of matrix organization will be vital to comprehensively evaluate new therapies.

Finally, the clinical use of TDPCs for treating tendon injuries is dependent on identifying a suitable tissue source, with minimal donor site morbidity. In general, a tenectomy procedure for isolating autologous TDPCs is more invasive than bone marrow aspiration. In our in vivo study, autologous equine TDPCs were derived from the lateral digital extensor tendon with minimal post-operative morbidity [32]. In human patients, healthy tendon autografts are routinely obtained from patellar $[120,121]$ and palmaris longus tendons [122], for cruciate and ulnar collateral ligament reconstruction surgeries, respectively. These sites could also be used for autogenous TDPC isolation. Further work is needed in this regard. Tendon tissues excised during reparative surgeries of Achilles tendon [123] and rotator cuff injuries [124] could also be used to isolate autogenous TDPCs; however, given the altered characteristics of TDPCs from pathological tissues, further research on these TDPCs is required before this possibility can be considered feasible. Allogeneic TDPCs can also be considered, as they avoid donorsite complications and culture delays that are required to generate clinically relevant autologous cell numbers. Although several in vivo experimental studies demonstrate the therapeutic benefits of allogeneic TDPCs, major regulatory and immunogenic concerns exists to prevent translating this option to human tendon injuries.

\section{Authorship and contributions}

This review article was written and edited by SSD and MCS. Both authors have read and approved the final manuscript.

\section{References}

1. Järvinen TA, Kannus P, Maffulli N, Khan KM (2005) Achilles tendon disorders: etiology and epidemiology. Foot Ankle Clin 10: 255-266. [Crossref]

2. Raikin SM, Garras DN, Krapchev PV (2013) Achilles tendon injuries in a United States population. Foot Ankle Int 34: 475-480. [Crossref]

3. Tashjian RZ1 (2012) Epidemiology, natural history, and indications for treatment of rotator cuff tears. Clin Sports Med 31: 589-604. [Crossref]

4. de Jong JP, Nguyen JT, Sonnema AJ, Nguyen EC, Amadio PC, et al. (2014) The incidence of acute traumatic tendon injuries in the hand and wrist: a 10-year populationbased study. Clin Orthop Surg 6: 196-202. [Crossref]
5. Goodship AE, Birch HL, Wilson AM (1994) The pathobiology and repair of tendon and ligament injury. Vet Clin North Am Equine Pract 10: 323-349. [Crossref]

6. Patterson-Kane JC, Firth EC (2009) The pathobiology of exercise-induced superficial digital flexor tendon injury in Thoroughbred racehorses. Vet $J$ 181: 79-89. [Crossref]

7. Gajhede-Knudsen M, Ekstrand J, Magnusson H, Maffulli N (2013) Recurrence of Achilles tendon injuries in elite male football players is more common after early return to play: an 11-year follow-up of the UEFA Champions League injury study. Br J Sports Med 47: 763-768. [Crossref]

8. Maffulli N, Longo UG, Spiezia F, Denaro V (2011) Aetiology and prevention of injuries in elite young athletes. Med Sport Sci 56: 187-200. [Crossref]

9. Best TM1 (1995) Muscle-tendon injuries in young athletes. Clin Sports Med 14: 669686. [Crossref]

10. Goh JC, Ouyang HW, Teoh SH, Chan CK, Lee EH (2003) Tissue-engineering approach to the repair and regeneration of tendons and ligaments. Tissue Eng 9 Suppl 1: S3144. [Crossref]

11. Nixon AJ, Watts AE, Schnabel LV (2012) Cell- and gene-based approaches to tendon regeneration. J Shoulder Elbow Surg 21: 278-294. [Crossref]

12. Gross G, Hoffmann A (2013) Therapeutic strategies for tendon healing based on novel biomaterials, factors and cells. Pathobiology 80: 203-210. [Crossref]

13. Docheva D, Müller SA, Majewski M, Evans CH (2015) Biologics for tendon repair Adv Drug Deliv Rev 84: 222-239. [Crossref]

14. Gaspar D, Spanoudes K, Holladay C, Pandit A, Zeugolis D (2015) Progress in cellbased therapies for tendon repair. Adv Drug Deliv Rev 84: 240-256. [Crossref]

15. Lui PP (2015) Stem cell technology for tendon regeneration: current status, challenges, and future research directions. Stem Cells Cloning 8: 163-174. [Crossref]

16. O'Brien M (1997) Structure and metabolism of tendons. Scand J Med Sci Sports 7: 55-61. [Crossref]

17. Benjamin M, Kaiser E, Milz S (2008) Structure-function relationships in tendons: a review. J Anat 212: 211-228. [Crossref]

18. Avery NC, Bailey AJ (2005) Enzymic and non-enzymic cross-linking mechanisms in relation to turnover of collagen: relevance to aging and exercise. Scand J Med Sci Sports 15: 231-240. [Crossref]

19. Thorpe CT, Clegg PD, Birch HL (2010) A review of tendon injury: why is the equine superficial digital flexor tendon most at risk? Equine Vet J 42: 174-180. [Crossref]

20. Thorpe CT, Riley GP, Birch HL, Clegg PD, Screen HR (2014) Fascicles from energystoring tendons show an age-specific response to cyclic fatigue loading. $J R$ Soc Interface 11: 20131058. [Crossref]

21. Thorpe CT, Godinho MS, Riley GP, Birch HL, Clegg PD, et al. (2015) The interfascicular matrix enables fascicle sliding and recovery in tendon, and behaves more elastically in energy storing tendons. J Mech Behav Biomed Mater 52: 85-94. [Crossref]

22. Thorpe CT, Klemt C, Riley GP, Birch HL, Clegg PD, et al. (2013) Helical sub-structures in energy-storing tendons provide a possible mechanism for efficient energy storage and return. Acta Biomater 9: 7948-7956. [Crossref]

23. Sharma P, Maffulli N (2006) Biology of tendon injury: healing, modeling and remodeling. J Musculoskelet Neuronal Interact 6: 181-190. [Crossref]

24. Alfredson H, Ohberg L, Forsgren S (2003) Is vasculo-neural ingrowth the cause of pain in chronic Achilles tendinosis? An investigation using ultrasonography and colour Doppler, immunohistochemistry, and diagnostic injections. Knee Surg Sports Traumatol Arthrosc 11: 334-338. [Crossref]

25. Fenwick SA, Hazleman BL, Riley GP (2002) The vasculature and its role in the damaged and healing tendon. Arthritis Res 4: 252-260.[Crossref]

26. Salingcarnboriboon R, Yoshitake H, Tsuji K, Obinata M, Amagasa T, et al. (2003) Establishment of tendon-derived cell lines exhibiting pluripotent mesenchymal stem cell-like property. Exp Cell Res 287: 289-300. [Crossref]

27. Bi Y, Ehirchiou D, Kilts TM, Inkson CA, Embree MC, et al. (2007) Identification of tendon stem/progenitor cells and the role of the extracellular matrix in their niche. Nat Med 13: 1219-1227. [Crossref]

28. Yin Z, Chen X, Chen JL, Shen WL, Hieu Nguyen TM, et al. (2010) The regulation of tendon stem cell differentiation by the alignment of nanofibers. Biomaterials 31 : 2163-2175. [Crossref]

29. Rui YF, Lui PP, Li G, Fu SC, Lee YW, et al. (2010) Isolation and characterization of multipotent rat tendon-derived stem cells. Tissue Eng Part A 16: 1549-1558. [Crossref] 
30. Zhang J, Wang JH (2010) Characterization of differential properties of rabbit tendon stem cells and tenocytes. BMC Musculoskelet Disord 11: 10. [Crossref]

31. Williamson KA, Lee KJ, Humphreys WJ, Comerford EJ, Clegg PD, et al. (2015) Restricted differentiation potential of progenitor cell populations obtained from the equine superficial digital flexor tendon (SDFT). J Orthop Res 33: 849-858. [Crossref]

32. Lui PPY (2015) Differential adhesion selection does not enrich for tendon-derived progenitor cells during in-vitro isolation and expansion. Stem Cell Res Ther 6: 106. [Crossref]

33. Randelli P, Conforti E, Piccoli M, Ragone V, Creo P, et al. (2013) Isolation and characterization of 2 new human rotator cuff and long head of biceps tendon cells possessing stem cell-like self-renewal and multipotential differentiation capacity. $\mathrm{Am} \mathrm{J}$ Sports Med 41: 1653-1664. [Crossref]

34. Utsunomiya H, Uchida S, Sekiya I, Sakai A, Moridera K, et al. (2013) Isolation and characterization of human mesenchymal stem cells derived from shoulder tissues involved in rotator cuff tears. Am J Sports Med 41: 657-668. [Crossref]

35. Durgam SS, Stewart AA, Pondenis HC, Yates AC, Evans RB, et al. (2012) Responses of equine tendon- and bone marrow-derived cells to monolayer expansion with fibroblast growth factor- 2 and sequential culture with pulverized tendon and insulin-like growth factor-I. Am J Vet Res 73: 162-170. [Crossref]

36. Rui YF, Lui PP, Lee YW, Chan KM (2012) Higher BMP receptor expression and BMP2 -induced osteogenic differentiation in tendon-derived stem cells compared with bonemarrow-derived mesenchymal stem cells. Int Orthop 36: 1099-1107. [Crossref]

37. Zhou Z, Akinbiyi T, Xu L, Ramcharan M, Leong DJ, et al. (2010) Tendon-derived stem/progenitor cell aging: defective self-renewal and altered fate. Aging Cell 9: 911915. [Crossref]

38. Kohler J, Popov C, Klotz B, Alberton P, Prall WC, et al. (2013) Uncovering the cellular and molecular changes in tendon stem/progenitor cells attributed to tendon aging and degeneration. Aging Cell 12: 988-999. [Crossref]

39. Zhang J, Pan T, Liu Y, Wang JH (2010) Mouse treadmill running enhances tendons by expanding the pool of tendon stem cells (TSCs) and TSC-related cellular production of collagen. J Orthop Res 28: 1178-1183. [Crossref]

40. Kowalski TJ, Leong NL, Dar A, Wu L, Kabir N, et al. (2015) Hypoxic culture conditions induce increased metabolic rate and collagen gene expression in ACL-derived cells. $J$ Orthop Res. [Crossref]

41. Mienaltowski MJ, Adams SM, Birk DE (2013) Regional differences in stem cell/ progenitor cell populations from the mouse achilles tendon. Tissue Eng Part A 19: 199-210. [Crossref]

42. Cadby JA, Buehler E, Godbout C, van Weeren PR, Snedeker JG (2014) Differences between the cell populations from the peritenon and the tendon core with regard to their potential implication in tendon repair. PLoS One 9: e92474. [Crossref]

43. Lee WY, Lui PP, Rui YF (2012) Hypoxia-mediated efficient expansion of human tendon-derived stem cells in vitro. Tissue Eng Part A 18: 484-498. [Crossref]

44. Zhang Y, Wang B, Zhang WJ, Zhou G, Cao Y, et al. (2010) Enhanced proliferation capacity of porcine tenocytes in low $\mathrm{O}_{2}$ tension culture. Biotechnol Lett 32: 181187. [Crossref]

45. Zhang J, Wang JH (2013) Human tendon stem cells better maintain their stemness in hypoxic culture conditions. PLoS One 8: e61424.[Crossref]

46. Tan Q, Lui PP, Rui YF (2012) Effect of in vitro passaging on the stem cell-related properties of tendon-derived stem cells-implications in tissue engineering. Stem Cells Dev 21: 790-800. [Crossref]

47. Tan Q, Lui PP, Lee YW (2013) In vivo identity of tendon stem cells and the roles of stem cells in tendon healing. Stem Cells Dev 22: 3128-3140. [Crossref]

48. de Mos M, Koevoet WJ, Jahr H, Verstegen MM, Heijboer MP, et al. (2007) Intrinsic differentiation potential of adolescent human tendon tissue: an in-vitro cell differentiation study. BMC Musculoskelet Disord 8: 16. [Crossref]

49. Stanco D, Viganò M, Orfei CP, DI Giancamillo A, Thiebat G, et al. (2015) In vitro characterization of stem/progenitor cells from semitendinosus and gracilis tendons as a possible new tool for cell-based therapy for tendon disorders. Joints 2: 159168. [Crossref]

50. Tan Q, Lui PP, Rui YF, Wong YM (2012) Comparison of potentials of stem cells isolated from tendon and bone marrow for musculoskeletal tissue engineering. Tissue Eng Part A 18: 840-851. [Crossref]

51. Ruzzini L, Abbruzzese F, Rainer A, Longo UG, Trombetta M, et al. (2014) Characterization of age-related changes of tendon stem cells from adult human tendons.
Knee Surg Sports Traumatol Arthrosc 22: 2856-2866. [Crossref]

52. Asai S, Otsuru S, Candela ME, Cantley L, Uchibe K, et al. (2014) Tendon progenitor cells in injured tendons have strong chondrogenic potential: the CD105negative subpopulation induces chondrogenic degeneration. Stem Cells 32: 32663277. [Crossref]

53. Zhang K, Asai S, Yu B, Enomoto-Iwamoto M (2015) IL-1 $\beta$ irreversibly inhibits tenogenic differentiation and alters metabolism in injured tendon-derived progenitor cells in vitro. Biochem Biophys Res Commun 463: 667-672. [Crossref]

54. Mori D, Funakoshi N, Yamashita F, Wakabayashi T3 (2015) Effect of fatty degeneration of the infraspinatus on the efficacy of arthroscopic patch autograft procedure for large to massive rotator cuff tears. Am J Sports Med 43: 1108-1117. [Crossref]

55. Deniz G, Kose O, Tugay A, Guler F, Turan A (2014) Fatty degeneration and atrophy of the rotator cuff muscles after arthroscopic repair: does it improve, halt or deteriorate. Arch Orthop Trauma Surg 134: 985-990. [Crossref]

56. Fu SC, Chan BP, Wang W, Pau HM, Chan KM, et al. (2002) Increased expression of matrix metalloproteinase 1 (MMP1) in 11 patients with patellar tendinosis. Acta Orthop Scand 73: 658-662. [Crossref]

57. Fu SC, Wang W, Pau HM, Wong YP, Chan KM, et al. (2002) Increased expression of transforming growth factor-betal in patellar tendinosis. Clin Orthop Relat Res 400 174-183. [Crossref]

58. Jones GC, Corps AN, Pennington CJ, Clark IM, Edwards DR, et al. (2006) Expression profiling of metalloproteinases and tissue inhibitors of metalloproteinases in norma and degenerate human achilles tendon. Arthritis Rheum 54: 832-842. [Crossref]

59. Maffulli N, Reaper J, Ewen SW, Waterston SW, Barrass V (2006) Chondral metaplasia in calcific insertional tendinopathy of the Achilles tendon. Clin J Sport Med 16: 329334. [Crossref]

60. Karousou E, Ronga M, Vigetti D, Passi A, Maffulli N (2008) Collagens, proteoglycans, MMP-, MMP-9 and TIMPs in human achilles tendon rupture. Clin Orthop Relat Res 466: 1577-1582. [Crossref]

61. Karousou E, Ronga M, Vigetti D, Barcolli D, Passi A, et al. (2010) Molecular interactions in extracellular matrix of tendon. Front Biosci (Elite Ed) 2: 1-12. [Crossref]

62. Fu SC, Chan KM, Rolf CG (2007) Increased deposition of sulfated glycosaminoglycans in human patellar tendinopathy. Clin J Sport Med 17: 129-134. [Crossref]

63. Lin L, Shen Q, Xue T, Yu C (2010) Heterotopic ossification induced by Achilles tenotomy via endochondral bone formation: expression of bone and cartilage related genes. Bone 46: 425-431. [Crossref]

64. Lui PP, Fu SC, Chan LS, Hung LK, Chan KM (2009) Chondrocyte phenotype and ectopic ossification in collagenase-induced tendon degeneration. J Histochem Cytochem 57: 91-100. [Crossref]

65. Daher RJ, Chahine NO, Razzano P, Patwa SA, Sgaglione NJ, et al. (2011) Tendon repair augmented with a novel circulating stem cell population. Int J Clin Exp Med 4: 214-219. [Crossref]

66. Mobasheri A, Shakibaei M (2013) Is tendinitis an inflammatory disease initiated and driven by pro-inflammatory cytokines such as interleukin $1 \beta$ ? Histol Histopathol 28 : 955-964. [Crossref]

67. Ko JY, Wang FS, Huang HY, Wang CJ, Tseng SL, et al. (2008) Increased IL-1bet expression and myofibroblast recruitment in subacromial bursa is associated with rotator cuff lesions with shoulder stiffness. J Orthop Res 26: 1090-1097. [Crossref]

68. Fedorczyk JM, Barr AE, Rani S, Gao HG, Amin M, et al. (2010) Exposure-dependent increases in IL-1beta, substance P, CTGF, and tendinosis in flexor digitorum tendons with upper extremity repetitive strain injury. J Orthop Res 28: 298-307. [Crossref]

69. Thorpe CT, Chaudhry S, Lei II, Varone A, Riley GP, et al. (2015) Tendon overload results in alterations in cell shape and increased markers of inflammation and matrix degradation. Scand J Med Sci Sports 25: e381-391. [Crossref]

70. Maeda T, Sakabe T, Sunaga A, Sakai K, Rivera AL, et al. (2011) Conversion of mechanical force into TGF-ß-mediated biochemical signals. Curr Biol 21: $933-$ 941. [Crossref]

71. Farhat YM, Al-Maliki AA, Chen T, Juneja SC, Schwarz EM, et al. (2012) Gene expression analysis of the pleiotropic effects of TGF- $\beta 1$ in an in vitro model of flexor tendon healing. PLoS One 7: e51411. [Crossref]

72. Loiselle AE, Yukata K, Geary MB, Kondabolu S, Shi S, et al. (2015) Development of antisense oligonucleotide (ASO) technology against Tgf- $\beta$ signaling to prevent scarring during flexor tendon repair. $J$ Orthop Res 33: 859-866. [Crossref] 
73. Jiang Y, Chen LK, Zhu DC, Zhang GR, Guo C, et al. (2010) The inductive effect of bone morphogenetic protein-4 on chondral-lineage differentiation and in situ cartilage repair. Tissue Eng Part A 16: 1621-1632. [Crossref]

74. Ma CB, Kawamura S, Deng XH, Ying L, Schneidkraut J, et al. (2007) Bone morphogenetic proteins-signaling plays a role in tendon-to-bone healing: a study of rhBMP-2 and noggin. Am J Sports Med 35: 597-604. [Crossref]

75. Rodeo SA, Suzuki K, Deng XH, Wozney J, Warren RF (1999) Use of recombinant human bone morphogenetic protein-2 to enhance tendon healing in a bone tunnel. $\mathrm{Am}$ J Sports Med 27: 476-488. [Crossref]

76. Martinek V, Latterman C, Usas A, Abramowitch S, Woo SL, et al. (2002) Enhancement of tendon-bone integration of anterior cruciate ligament grafts with bone morphogenetic protein-2 gene transfer: a histological and biomechanical study. J Bone Joint Surg Am 84-84A: 1123-31. [Crossref]

77. Chen CH, Liu HW, Tsai CL, Yu CM, Lin IH, et al. (2008) Photoencapsulation of bone morphogenetic protein-2 and periosteal progenitor cells improve tendon graft healing in a bone tunnel. Am J Sports Med 36: 461-473. [Crossref]

78. Lui PP, Chan LS, Cheuk YC, Lee YW, Chan KM (2009) Expression of bone morphogenetic protein-2 in the chondrogenic and ossifying sites of calcific tendinopathy and traumatic tendon injury rat models. J Orthop Surg Res 4: 27. [Crossref]

79. Yee Lui PP, Wong YM, Rui YF, Lee YW, Chan LS, et al. (2011) Expression of chondroosteogenic BMPs in ossified failed tendon healing model of tendinopathy. J Orthop Res 29: 816-821. [Crossref]

80. Hashimoto Y, Yoshida G, Toyoda H, Takaoka K (2007) Generation of tendon-to-bone interface "enthesis" with use of recombinant BMP-2 in a rabbit model. J Orthop Res 25: 1415-1424. [Crossref]

81. Cook JL, Feller JA, Bonar SF, Khan KM (2004) Abnormal tenocyte morphology is more prevalent than collagen disruption in asymptomatic athletes' patellar tendons. $J$ Orthop Res 22: 334-338. [Crossref]

82. Spiesz EM, Thorpe CT, Chaudhry S, Riley GP, Birch HL, et al. (2015) Tendon extracellular matrix damage, degradation and inflammation in response to in vitro overload exercise. J Orthop Res 33: 889-897. [Crossref]

83. Lui PP, Chan LS, Lee YW, Fu SC, Chan KM (2010) Sustained expression of proteoglycans and collagen type III/type I ratio in a calcified tendinopathy model. Rheumatology 49: 231-239. [Crossref]

84. Riley GP, Harrall RL, Constant CR, Chard MD, Cawston TE, et al. (1994) Glycosaminoglycans of human rotator cuff tendons: changes with age and in chronic rotator cuff tendinitis. Ann Rheum Dis 53: 367-376. [Crossref]

85. Malcarney HL, Murrell GA (2003) The rotator cuff: biological adaptations to its environment. Sports Med 33: 993-1002. [Crossref]

86. Dourte LM, Pathmanathan L, Mienaltowski MJ, Jawad AF, Birk DE, et al. (2013) Mechanical, compositional, and structural properties of the mouse patellar tendon with changes in biglycan gene expression. J Orthop Res 31: 1430-1437. [Crossref]

87. Yoon JH, Halper J (2005) Tendon proteoglycans: biochemistry and function. $J$ Musculoskelet Neuronal Interact 5: 22-34. [Crossref]

88. Zhang G, Ezura Y, Chervoneva I, Robinson PS, Beason DP, et al. (2006) Decorin regulates assembly of collagen fibrils and acquisition of biomechanical properties during tendon development. J Cell Biochem 98: 1436-1439. [Crossref]

89. Dunkman AA, Buckley MR, Mienaltowski MJ, Adams SM, Thomas SJ, et al. (2013) Decorin expression is important for age-related changes in tendon structure and mechanical properties. Matrix Biol 32: 3-13. [Crossref]

90. Abbah SA, Thomas D, Browne S, et al. (2016) Co-transfection of decorin and interleukin-10 modulates pro-fibrotic extracellular matrix gene expression in human tenocyte culture. Sci Rep 6: 20922. [Crossref]

91. Dahlgren LA, van der Meulen MC, Bertram JE, Starrak GS, Nixon AJ (2002) Insulinlike growth factor-I improves cellular and molecular aspects of healing in a collagenaseinduced model of flexor tendinitis. J Orthop Res 20: 910-919. [Crossref]

92. Dahlgren LA, Mohammed HO, Nixon AJ (2005) Temporal expression of growth factors and matrix molecules in healing tendon lesions. J Orthop Res 23: 84-92. [Crossref]

93. Rui YF, Lui PP, Ni M, Chan LS, Lee YW, et al. (2011) Mechanical loading increased BMP-2 expression which promoted osteogenic differentiation of tendon-derived stem cells. J Orthop Res 29: 390-396. [Crossref]

94. Popov C, Burggraf M, Kreja L, Ignatius A, Schieker M, et al. (2015) Mechanical stimulation of human tendon stem/progenitor cells results in upregulation of matrix proteins, integrins and MMPs, and activation of p38 and ERK1/2 kinases. BMC Mol Biol 16: 6. [Crossref]

95. Zhang AY, Bates SJ, Morrow E, Pham H, Pham B, et al. (2009) Tissue-engineered intrasynovial tendons: optimization of acellularization and seeding. J Rehabil Res Dev 46: 489-498. [Crossref]

96. Chong AK, Riboh J, Smith RL, Lindsey DP, Pham HM, et al. (2009) Flexor tendon tissue engineering: acellularized and reseeded tendon constructs. Plast Reconstr Sur 123: 1759-1766.[Crossref]

97. Stewart AA, Barrett JG, Byron CR, Yates AC, Durgam SS, et al. (2009) Comparison of equine tendon-, muscle-, and bone marrow-derived cells cultured on tendon matrix. $\mathrm{Am}$ $J$ Vet Res 70: 750-757. [Crossref]

98. Durgam SS, Stewart AA, Pondenis HC, Gutierrez-Nibeyro SM, Evans RB, et al. (2012) Comparison of equine tendon- and bone marrow-derived cells cultured on tendon matrix with or without insulin-like growth factor-I supplementation. Am J Vet Res 73 153-161. [Crossref]

99. Cao Y, Liu Y, Liu W, Shan Q, Buonocore SD, et al. (2002) Bridging tendon defects using autologous tenocyte engineered tendon in a hen model. Plast Reconstr Surg 110: 1280-1289. [Crossref]

100. Ni M, Lui PP, Rui YF, Lee YW, Lee YW, et al. (2012) Tendon-derived stem cells (TDSCs) promote tendon repair in a rat patellar tendon window defect model. $J$ Orthop Res 30: 613-619. [Crossref]

101. Tan C, Lui PP, Lee YW, Wong YM1 (2014) Scx-transduced tendon-derived stem cells (tdscs) promoted better tendon repair compared to mock-transduced cells in a rat patellar tendon window injury model. PLoS One 9: e97453. [Crossref]

102. Durgam SS, Stewart AA, Sivaguru M, Johnson AJ, Stewart MC (2016) Tendonderived progenitor cells improve healing of collagenase-induced flexor tendinitis. $J$ Orthop Res . [Crossref]

103. Schnabel LV, Lynch ME, van der Meulen MC, Yeager AE, Kornatowski MA, et al. (2009) Mesenchymal stem cells and insulin-like growth factor-I gene-enhanced mesenchymal stem cells improve structural aspects of healing in equine flexor digitorum superficialis tendons. J Orthop Res 27: 1392-1398. [Crossref]

104. Nixon AJ, Dahlgren LA, Haupt JL, Yeager AE, Ward DL (2008) Effect of adiposederived nucleated cell fractions on tendon repair in horses with collagenase-induced tendinitis. Am J Vet Res 69: 928-937. [Crossref]

105. Watts AE, Yeager AE, Kopyov OV, Nixon AJ (2011) Fetal derived embryonic-like stem cells improve healing in a large animal flexor tendonitis model. Stem Cell Res Ther 2: 4. [Crossref]

106. Awad HA, Boivin GP, Dressler MR, Smith FN, Young RG, et al. (2003) Repair of patellar tendon injuries using a cell-collagen composite. J Orthop Res 21: 420431. [Crossref]

107. Chen CH, Cao Y, Wu YF, Bais AJ, Gao JS, et al. (2008) Tendon healing in vivo: gene expression and production of multiple growth factors in early tendon healing period. $J$ Hand Surg Am 33: 1834-1842. [Crossref]

108. Lee CH, Lee FY, Tarafder S, Kao K, Jun Y, et al. (2015) Harnessing endogenous stem/ progenitor cells for tendon regeneration. J Clin Invest 125: 2690-2701. [Crossref]

109. Ni M, Rui YF, Tan Q, Liu Y, Xu LL, et al. (2013) Engineered scaffold-free tendon tissue produced by tendon-derived stem cells. Biomaterials 34: 2024-2037. [Crossref]

110. Lui PP, Wong OT, Lee YW (2016) Transplantation of tendon-derived stem cells pre-treated with connective tissue growth factor and ascorbic acid in vitro promoted better tendon repair in a patellar tendon window injury rat model. Cytotherapy 18 : 99-112. [Crossref]

111. Bosch G, van Schie HT, de Groot MW, Cadby JA, van de Lest CH, et al. (2010) Effects of platelet-rich plasma on the quality of repair of mechanically induced core lesions in equine superficial digital flexor tendons: A placebo-controlled experimental study. $J$ Orthop Res 28: 211-217. [Crossref]

112. de Mos M, van der Windt AE, Jahr H, van Schie HT, Weinans H, et al. (2008) Can platelet-rich plasma enhance tendon repair? A cell culture study. Am J Sports Med 36: 1171-1178. [Crossref]

113. Chen L, Dong SW, Tao X, Liu JP, Tang KL, et al. (2012) Autologous platelet-rich clot releasate stimulates proliferation and inhibits differentiation of adult rat tendon stem cells towards nontenocyte lineages. J Int Med Res 40: 1399-1409. [Crossref]

114. Chen L, Dong SW, Liu JP, Tao X, Tang KL, et al. (2012) Synergy of tendon stem cells and platelet-rich plasma in tendon healing. J Orthop Res 30: 991-997. [Crossref]

115. Chen L, Liu JP, Tang KL, Wang Q, Wang GD, et al. (2014) Tendon derived stem cells 
promote platelet-rich plasma healing in collagenase-induced rat achilles tendinopathy. Cell Physiol Biochem 34: 2153-2168. [Crossref]

116. Jiang D, Xu B, Yang M, Zhao Z, Zhang Y, et al. (2014) Efficacy of tendon stem cells in fibroblast-derived matrix for tendon tissue engineering. Cytotherapy 16: 662673. [Crossref]

117. Favata M, Beredjiklian PK, Zgonis MH, Beason DP, Crombleholme TM, et al (2006) Regenerative properties of fetal sheep tendon are not adversely affected by transplantation into an adult environment. J Orthop Res 24: 2124-2132. [Crossref]

118. Guest DJ, Smith MR, Allen WR (2010) Equine embryonic stem-like cells and mesenchymal stromal cells have different survival rates and migration patterns following their injection into damaged superficial digital flexor tendon. Equine Vet $J$ 42: 636-642. [Crossref]

119. Sole A, Spriet M, Padgett KA, Vaughan B, Galuppo LD, et al. (2013) Distribution and persistence of technetium-99 hexamethyl propylene amine oxime-labeled bone marrow-derived mesenchymal stem cells in experimentally induced tendon lesions after intratendinous injection and regional perfusion of the equine distal limb. Equine Vet $J$ 45: 726-731. [Crossref]
120. Konrads C, Reppenhagen S, Plumhoff P, Hoberg M, Rudert M, et al. (2016) No significant difference in clinical outcome and knee stability between patellar tendon and semitendinosus tendon in anterior cruciate ligament reconstruction. Arch Orthop Trauma Surg 136: 521-525. [Crossref]

121. Zoran Z, Ivan V, Egon B, Dubravka B, Vjekoslav W3, et al. (2015) Knee stability after arthroscopic anterior cruciate ligament reconstruction using the middle third of the patellar ligament and quadrupled hamstring tendons grafts - A two-year follow-up. Injury 46 Suppl 6: S91-95. [Crossref]

122. Erickson BJ, Harris JD, Chalmers PN, Bach BR Jr, Verma NN, et al. (2015) Ulnar Collateral Ligament Reconstruction: Anatomy, Indications, Techniques, and Outcomes. Sports Health 7: 511-517. [Crossref]

123. Corradino B, Di Lorenzo S, Calamia C, Moschella F (2015) Surgical repair of acute Achilles tendon rupture with an end-to-end tendon suture and tendon flap. Injury 46 : 1637-1640. [Crossref]

124. Valencia Mora M, Ruiz Ibán MA, Díaz Heredia J, Barco Laakso R, Cuéllar R, et al. (2015) Stem cell therapy in the management of shoulder rotator cuff disorders. World J Stem Cells 7: 691-699. [Crossref]

Copyright: (2016 Durgam SS. This is an open-access article distributed under the terms of the Creative Commons Attribution License, which permits unrestricted use, distribution, and reproduction in any medium, provided the original author and source are credited. 